\title{
E-commerce Challenges, Solutions and Effectiveness Perspective Bangladesh
}

\author{
Ohidujjaman \\ MSCSE \\ Department of Computer Science \\ and Engineering \\ United International University, \\ Dhaka, Bangladesh.
}

\author{
Mahmudul Hasan \\ Lecturer \\ Department of Computer Science \\ and Engineering \\ Comilla University, \\ Comilla, Bangladesh.
}

\author{
Mohammad Nurul Huda \\ Associate Professor \\ Department of Computer Science \\ and Engineering \\ United International University, \\ Dhaka, Bangladesh
}

\begin{abstract}
Due to increasing the Information Technology around the world have a strong role in business sector that have already turned into online business many year past. This online business refers to the E-commerce which is recently moved in to developing countries like Bangladesh (BD). This paper describes the present challenges of E-commerce and it's solution in BD. It also discusses the effectiveness of E-commerce in financial sector of BD .Proper Ecommerce sites like Brand Ecommerce play a vital role in employment generation as well as increasing the internet utilization .This research mainly describes the present status of BD's E-commerce sites as well as study of traditional commerce for developing online business.
\end{abstract}

By surveying fruitful questionnaire from consumer site, Ecommerce services provider related parties, banking sector give a perfect assessment of BD's present E-commerce infrastructure and its future organizational structure. Market middlemen, and industry and firm value chain are the most involvement in traditional businesses. Online marketplace eliminates that involvement by creating an alternative channel from producer or manufacturer to consumers or audiences via Web [10]. As a developing country BD is not well known about IT sector. As a result this paper also shows how to reach digital Bangladesh. The comparative analysis of different Ecommerce sites represents an analytical initiative. This research compares the local E-commerce sites with worldwide brand E-commerce sites to make an effective solution of BD's E-commerce.

\section{Keywords}

E-business, E-commerce, Market middlemen, Supply chain, Transaction costs, M-commerce

\section{INTRODUCTION}

\subsection{Background}

The initiate of internet the large planet named world become a tiny one. Both the globalization and internet have the prospective to offer a lot of benefits to individuals and organizational in developing as well as developed countries. Internet and ecommerce are closely wrapped towards developed countries. But they can achieve tremendous benefits to developing countries if it is applicable as an ideal business purpose. Ecommerce is a revolution in business practices.

In the whole world the potential economic is dependent on business sector. Long period past in the first world countries ,their business is in online marketplace .That is a traffic turn in business sector for saving time, eliminating market middlemen, reduction of necessary product cost, visiting a free- dom marketplace, ensuring the quality of products and opportunity for checking the product prices as well as save the transportation cost for consumer mobility.

Geographically Bangladesh is an agriculture based country. But, It has lots of population like 161 millions now [15]. According to its area population density is very high. Since this country is an agricultural based, but it is known to all agriculture is the raw materials of the industry. In every country industry is the creator of business sector. However, BD can use their large number of population in a potential business arena including agriculture sector.

All over the world there is none country whose population density is like Bangladesh. But every first world country all kinds of institutions, firms, industry and organization are proper distributed. In BD all type of demand for population can be found either capital (Dhaka) or city area. Consequently online market is effective in this country. As mention that in this country market middlemen are involved in all type of business sector. That creates an artificial extra products cost. It is a developing country, so the communication infrastructure is not suited. As a result physically movement to buy a product is a time consuming for the consumer. This discussion creates a demand for proper online marketplace.

Development countries smoothly run worldwide brand Ecommerce site like Amazon, eBay, Walmart.com, LLBeandn.com, Sony.com etc. As well as a larger number of firms from developing countries such as South Korea, Taiwan, Israel, Brazil and India have already become global players in many industries [4]. To fully exploit the potential of the internet and E-commerce, policy makers in developing as well as industrialized countries are taking initiatives to develop the global information infrastructure (GII) and connect their national infrastructures to the (GII).

Global E-commerce amounted to US\$ 26 billion in 1997(OECD 2001) and estimated to exceed US\$ 5 trillion in 2001.In 2007, total B2C revenue were about \$225 billion. Largest form of E-commerce amounted \$3.6 trillion in transactions in USA, 2007 [4] whereas, BD is new born in Ecommerce business arena. BD's existing sites are not well organized as well as they cannot run online business smoothly though BD is in now the facility of $3^{\text {rd }}$ generation ( $3 \mathrm{~g}$ ) internet services. In future, online business strategy can bring glorious opportunity this developing country if it can be applied in proper business purposes including all e-commerce business dimensions such as B2B, B2C, C2C and M-commerce [11].

\subsection{Evolution of E-commerce}

Although E-commerce is a very recent phenomenon of the late 1990s, it already has a brief chaotic history. The history of E-commerce can be divided into three periods. They are innovation, consolidation and reinvention periods. 
Table 1. Evolution of E-commerce [10]

\begin{tabular}{|c|c|c|}
\hline \multicolumn{3}{|c|}{ Evolution of E-commerce } \\
\hline $\begin{array}{l}\text { 1995-2000 } \\
\text { (Innovation) }\end{array}$ & $\begin{array}{l}2001-2006 \\
\text { (Consolidation) }\end{array}$ & $\begin{array}{l}\text { 2006-Futuire } \\
\text { (Reinvention) }\end{array}$ \\
\hline $\begin{array}{l}\text { Technology- } \\
\text { driven }\end{array}$ & $\begin{array}{l}\text { Business- } \\
\text { driven }\end{array}$ & $\begin{array}{l}\text { Audience, customer and } \\
\text { Community- driven }\end{array}$ \\
\hline $\begin{array}{l}\begin{array}{l}\text { Revenue } \\
\text { growth em- } \\
\text { phasis }\end{array} \\
\end{array}$ & $\begin{array}{l}\text { Earnings and } \\
\text { profits empha- } \\
\text { sis }\end{array}$ & $\begin{array}{ll}\text { Audience and social } \\
\text { network } \\
\text { growth emphasis }\end{array}$ \\
\hline $\begin{array}{l}\text { Venture capi- } \\
\text { tal financing }\end{array}$ & $\begin{array}{l}\text { Traditional } \\
\text { financing }\end{array}$ & $\begin{array}{l}\text { Smaller VC investments; } \\
\text { early small firm buyouts } \\
\text { by large online players }\end{array}$ \\
\hline Ungoverned & $\begin{array}{l}\text { Stronger regu- } \\
\text { lation and gov- } \\
\text { ernance }\end{array}$ & $\begin{array}{l}\text { Extensive government } \\
\text { Surveillance }\end{array}$ \\
\hline $\begin{array}{l}\text { Entrepreneur- } \\
\text { ial }\end{array}$ & $\begin{array}{l}\text { Large tradi- } \\
\text { tional firms }\end{array}$ & $\begin{array}{l}\text { Large pure Web-based } \\
\text { firms }\end{array}$ \\
\hline $\begin{array}{l}\text { Disintermedi- } \\
\text { ation }\end{array}$ & $\begin{array}{l}\text { Strengthening } \\
\text { intermediaries }\end{array}$ & $\begin{array}{l}\text { Proliferation of small } \\
\text { online intermediaries } \\
\text { renting business process- } \\
\text { es of larger firms }\end{array}$ \\
\hline $\begin{array}{l}\text { Perfect mar- } \\
\text { kets }\end{array}$ & $\begin{array}{l}\text { Imperfect mar- } \\
\text { kets, brands } \\
\text { and network } \\
\text { effect. } \\
\end{array}$ & $\begin{array}{l}\text { Continuation of online } \\
\text { market imperfections; } \\
\text { commodity competition } \\
\text { in select markets. }\end{array}$ \\
\hline $\begin{array}{l}\text { Pure online } \\
\text { strategies }\end{array}$ & $\begin{array}{l}\text { Mixed "bricks } \\
\text { and clicks" } \\
\text { Strategies }\end{array}$ & $\begin{array}{l}\text { Return of pure online } \\
\text { strategies in new mar- } \\
\text { kets; extension of bricks } \\
\text { and clicks in traditional } \\
\text { retail markets. }\end{array}$ \\
\hline $\begin{array}{l}\text { First-mover } \\
\text { advantages }\end{array}$ & $\begin{array}{l}\text { Strategic fol- } \\
\text { lower strength; } \\
\text { complementary } \\
\text { assets }\end{array}$ & $\begin{array}{l}\text { First mover-advantages } \\
\text { return in new markets as } \\
\text { traditional Web players } \\
\text { catch up }\end{array}$ \\
\hline $\begin{array}{ll}\text { Low } & \text { com- } \\
\text { plexity } & \text { retail } \\
\text { products } & \end{array}$ & $\begin{array}{ll}\text { High } & \text { com- } \\
\text { plexity } & \text { retail } \\
\text { products } & \end{array}$ & services \\
\hline
\end{tabular}

\section{RECENT ISSUES AND DEVELOPMENTS}

E-commerce is the very recent trend in business regarding to Bangladesh. Many people are trying to develop its activities related to different views. This work studied basically existing almost recent related tasks. Three recent works out of them are sequentially depicted as follows.

\subsection{E-commerce aspect of Developing Countries like Bangladesh (March 2011)}

Table 2. Analytical report of $2.1[1]$

\begin{tabular}{|l|l|l|}
\hline Major issues & Research & Hypothesis \\
\hline \multirow{2}{*}{$\begin{array}{l}\text { First mover } \\
\text { activity }\end{array}$} & $\begin{array}{l}\text { Nature of the } \\
\text { lompany. } \\
\text { Number of the } \\
\text { employees. } \\
\text { Company's } \\
\text { internet } \\
\text { experience. }\end{array}$ & $\begin{array}{l}\text { This paper emphasis on } \\
\text { indication online mar- } \\
\text { ketplace opportunity. } \\
\text { Specified as first mover } \\
\text { for traditional business. }\end{array}$ \\
\hline
\end{tabular}

\begin{tabular}{|c|c|c|}
\hline $\begin{array}{l}\text { E-commerce } \\
\text { web site } \\
\text { developm-ent } \\
\text { and maintena- } \\
\text { nce process }\end{array}$ & No mentioned & $\begin{array}{l}\text { This issue is a continues } \\
(99.99+) \\
\text { Process and provides } \\
\text { service as } 24 / 7 \text {. }\end{array}$ \\
\hline Internet issue & $\begin{array}{l}\text { Company's } \\
\text { internet expe- } \\
\text { rience. } \\
\text { NO. Of com- } \\
\text { puter literate } \\
\text { officer. } \\
\text { Mode of the } \\
\text { Internet us- } \\
\text { age. }\end{array}$ & $\begin{array}{l}\text { This issue is poorly } \\
\text { described. Just specified } \\
\text { the internet usage level } \\
\text { of merchant expressed } \\
\text { as percentage result. } \\
\text { Dial up, Broad band and } \\
\text { office automation as a } \\
\text { mode of internet usage } \\
\text { result. No details infra- } \\
\text { structure of internet for } \\
\text { an E-commerce. }\end{array}$ \\
\hline $\begin{array}{l}\text { Revenue } \\
\text { model }\end{array}$ & $\begin{array}{l}\text { Revenue of } \\
\text { the company. } \\
\text { Profit of the } \\
\text { company. }\end{array}$ & $\begin{array}{l}\text { Several types of revenue } \\
\text { model are not point out } \\
\text { at all. Just express the } \\
\text { revenue and profit of the } \\
\text { firms. Here sales of } \\
\text { goods are the revenue } \\
\text { model. }\end{array}$ \\
\hline $\begin{array}{l}\text { Payment sys- } \\
\text { tem agree- } \\
\text { ment }\end{array}$ & No mentioned & $\begin{array}{l}\text { For secure online value } \\
\text { transaction this issue is } \\
\text { the most essential. }\end{array}$ \\
\hline $\begin{array}{l}\text { Transportati- } \\
\text { on agreement }\end{array}$ & No mentioned & $\begin{array}{l}\text { For successful shipping } \\
\text { this issue is efficient. }\end{array}$ \\
\hline $\begin{array}{l}\text { Multiple busi- } \\
\text { ness dimen- } \\
\text { sions }\end{array}$ & Only B2B & $\begin{array}{l}\text { But no specified about } \\
\text { B2C,C2C,M-commerce, } \\
\text { P2P }\end{array}$ \\
\hline $\begin{array}{l}\text { Target audi- } \\
\text { ence or con- } \\
\text { sumer study }\end{array}$ & Not specified & $\begin{array}{l}\text { To run an E-commerce } \\
\text { must prophecy of con- } \\
\text { sumers }\end{array}$ \\
\hline $\begin{array}{l}\text { Privacy policy } \\
\text { of merchant } \\
\text { side }\end{array}$ & Not specified & $\begin{array}{l}\text { This issue protects main- } \\
\text { ly consumer's privacy } \\
\text { monitored by the mer- } \\
\text { chant side. }\end{array}$ \\
\hline
\end{tabular}

\subsection{E-Commerce in Bangladesh: Status, Po- tential and Constraints}

Table3. Sketch of limitations of the paper. [2]

\begin{tabular}{|l|l|}
\hline Swot up area & Sketch Of Limitation \\
\hline $\begin{array}{l}\text { Dimensions of the } \\
\text { business }\end{array}$ & $\begin{array}{l}\text { B2B, B2C and B2G are specified. } \\
\text { But Emerging model C2C, M- } \\
\text { commerce is not specified. Also P2P } \\
\text { is not depicted. }\end{array}$ \\
\hline $\begin{array}{l}\text { Ecommerce web } \\
\text { site development } \\
\text { and maintenance }\end{array}$ & Not specified about this issue \\
\hline $\begin{array}{l}\text { Internet status and } \\
\text { issues }\end{array}$ & $\begin{array}{l}\text { Directly this issue is in BTTB. But } \\
\text { there is no well depiction about inter- } \\
\text { net infrastructure for E-commerce }\end{array}$ \\
\hline Disintermediaries & $\begin{array}{l}\text { Well description about business di- } \\
\text { mension but no stresses how would } \\
\text { be eliminated market middlemen. }\end{array}$ \\
\hline Shipment policy & $\begin{array}{l}\text { As E-commerce purpose no shipping } \\
\text { agreement. }\end{array}$ \\
\hline $\begin{array}{l}\text { Audience Analy- } \\
\text { sis }\end{array}$ & Not specified \\
\hline
\end{tabular}




\begin{tabular}{|l|l|}
\hline $\begin{array}{l}\text { Payment via } \\
\text { clearing house }\end{array}$ & $\begin{array}{l}\text { Only specified Payment system via } \\
\text { bank but the procedure is not } \\
\text { sketched. Not identified clearing } \\
\text { house. }\end{array}$ \\
\hline Revenue model & $\begin{array}{l}\text { Just identified revenue and profit of } \\
\text { the firms but what types of revenue } \\
\text { model are there, is not stated. }\end{array}$ \\
\hline $\begin{array}{l}\text { Online market- } \\
\text { place }\end{array}$ & $\begin{array}{l}\text { Did not touch Online marketplace } \\
\text { commencement. }\end{array}$ \\
\hline $\begin{array}{l}\text { Cultural tradition } \\
\text { Issue }\end{array}$ & Not point out. \\
\hline
\end{tabular}

\subsection{Present Status and Critical Success fac-} tor of E-commerce in Bangladesh

Constriction of this paper [3] Perspective developing country:

$\checkmark$ Vital outcome success factor are not highlighted (Elimination market middlemen, multiple revenue aspect, time, first mover opportunity etc.)

$\checkmark \quad$ No details about online marketplace

$\checkmark$ Consumer analysis is skipped

$\checkmark$ No touch to E-commerce site development in business purpose.

$\checkmark \quad$ No details role of Internet for online market.

$\checkmark$ Online banking role is omit

$\checkmark$ Several payment systems are not specified

$\checkmark$ Product and services shipping policy was not found.

$\checkmark$ Only three business models are expressed (C2C, Mcommerce are skipped)

$\checkmark$ There is no privacy policy sketch.

$\checkmark$ Lack of depicted foreign currencies approval.

$\checkmark \quad$ No specified third party involvement in value payment (e.g. clearing house)

$\checkmark \quad$ Not spoken cultural tradition to buy product

\section{EXISTING SCENARIO OF E-COMMERCE IN BANGLADESH}

To online business purpose several E-commerce sites are found in Bangladesh. They serve more likely equivalent business dimensions. Their revenue model is several categories. As well as payment systems are also more similar. According to Alexa traffic rank some of the Bangladeshi E-commerce sites are evaluated.

Table 4. Foremost Bangladeshi E-commerce sites [17]

\begin{tabular}{|l|c|c|}
\hline Site Name & Alexa Rank & BD Rank \\
\hline Bikroy.com & 8,516 & 25 \\
\hline Clickbd.com & 10,344 & 44 \\
\hline Cellbazaar.com & 10,496 & 36 \\
\hline Rokomari.com & 67,592 & 240 \\
\hline Hutbazar.com & 267,801 & 1,020 \\
\hline
\end{tabular}

This study analyzes some E-commerce in BD applying several key factors. Mainly these major factors manipulate to establish an ideal E-commerce infrastructure.

Major Attributes to establish an ideal E-commerce are as follows: $\checkmark \quad 8$ Key Elements of Business model

$\checkmark 8$ Unique Features of E-commerce Technology

$\checkmark$ Business Dimensions / Models

$\checkmark$ Revenue Model

$\checkmark$ Target audiences

$\checkmark \quad$ E-commerce Website Methodology

$\checkmark$ Secure and quick payment system

$\checkmark$ Currencies Support

$\checkmark$ Shipping policies

$\checkmark$ Collection of multiplicity

$\checkmark \quad$ Businesses cover up arena

$\checkmark$ Privacy policy

.The SWOT (Strengthens Weakness Opportunities Threat) analysis is the following on the several existing E-commerce site.

\subsection{Bikroy.com}

Table 5. SWOT analysis of bikroy.com [18]

\begin{tabular}{|c|c|c|c|}
\hline & Helpful & Destructive & \\
\hline 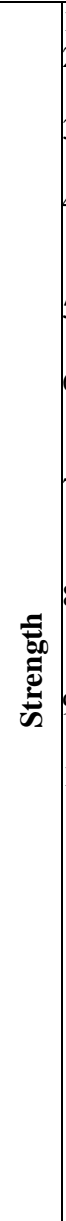 & 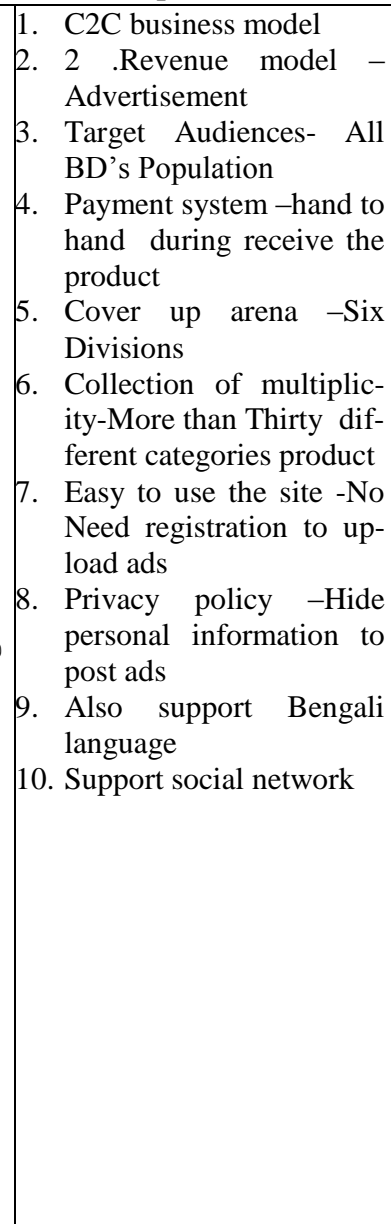 & $\begin{array}{l}\text { 1. No value proposi- } \\
\text { tion - Most of the } \\
\text { products are old. } \\
\text { 2. } \text { C2C causes Con- } \\
\text { sumer generated } \\
\text { business model. } \\
\text { 3. Lack of B2B, B2C } \\
\text { business model. } \\
\text { 4. No Multiple revenue } \\
\text { model-Sales of } \\
\text { goods, Transaction } \\
\text { fees, Subscription } \\
\text { fees, Affiliate. } \\
\text { 5. No online payment } \\
\text { system. } \\
\text { 6. Shipping policy -up } \\
\text { to consumers. } \\
\text { 7. Site design - Can- } \\
\text { not see the products } \\
\text { in different dimen- } \\
\text { sion, no shopping } \\
\text { cart option. } \\
\text { 8. Currency support - } \\
\text { Only BDT/Taka. } \\
\text { 9. Global rich- no } \\
\text { support. } \\
\text { 10. No Competitive } \\
\text { advantages- As As } \\
\text { Consumer gener- } \\
\text { ated. } \\
\text { 11. Lack of Market } \\
\text { opportunity - Not } \\
\text { include multiple } \\
\text { business model }\end{array}$ & $\frac{\vec{E}}{\tilde{E}}$ \\
\hline
\end{tabular}




\begin{tabular}{|c|c|c|c|c|}
\hline 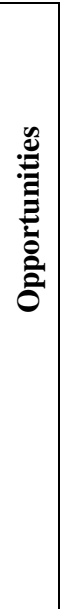 & & $\begin{array}{l}\text { Has option to turn Multi- } \\
\text { ple business model } \\
\text { Has chance to eliminate } \\
\text { market middlemen } \\
\text { Can create employment } \\
\text { Audiences may gather IT } \\
\text { knowledge } \\
\text { Option to run secure } \\
\text { Online payment system- } \\
\text { that helps one step to run } \\
\text { E -banking } \\
\text { M-commerce - that may } \\
\text { cover all target audi- } \\
\text { ences } \\
\text { Marketing - that may } \\
\text { bring first mover facility }\end{array}$ & $\begin{array}{l}\text { 1. Market strategy } \\
\text { may fail -because } \\
\text { user generated. } \\
\text { 2. Products are old- } \\
\text { User may reduce } \\
\text { 3. Risk of hand to } \\
\text { hand transactions - } \\
\text { because of dishon- } \\
\text { est user policy } \\
\text { 4. Shipping may } \\
\text { time consuming -so } \\
\text { consumer mater one } \\
\text { move to better on } \\
\text { 5irm profit may fall } \\
\text { down - Because of } \\
\text { limited revenue } \\
\text { model }\end{array}$ & 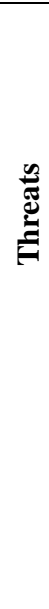 \\
\hline
\end{tabular}

\subsection{Clickbd.com}

Table 6. SWOT analysis of Clickbd.com [19]

\begin{tabular}{|c|c|c|c|}
\hline \multicolumn{2}{|r|}{ Helpful } & \multicolumn{2}{|l|}{ Destructive } \\
\hline 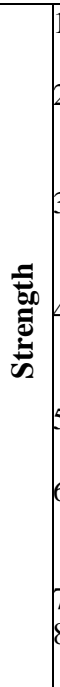 & $\begin{array}{l}\text { 1.B2B,B2C,C2C business } \\
\text { model -Ads, } \\
\text { 2.Revenue model -Ae } \\
\text { Sales of goods, Subscrip- } \\
\text { tion fees, Transaction fees } \\
\text { 3.Target Audiences- City } \\
\text { corporation area and large } \\
\text { district level town. } \\
\text { 4.Payment system -Click } \\
\text { card, cheque, Cash at } \\
\text { home, Courier pay } \\
\text { 5.Collection of multiplicity- } \\
\text { Large collection } \\
\text { 6.Privacy policy -Personal } \\
\text { information is securely } \\
\text { stored in clickbd server. } \\
\text { 7.Support social network } \\
\text { 8. In ClickBD over 90\% of } \\
\text { all listed items get sold. }\end{array}$ & $\begin{array}{l}\text { 1. } \begin{array}{l}\text { Online payment } \\
\text { system- Use only } \\
\text { click card }\end{array} \\
\text { 2. No affiliate revenue } \\
\text { model } \\
\text { 3. Shipping policy - } \\
\text { No proper shipping } \\
\text { policies } \\
\text { 4. Site design - Can- } \\
\text { not see the products } \\
\text { in different dimen- } \\
\text { sion, no shopping } \\
\text { cart option, not easy } \\
\text { to access the site. } \\
\text { 5. Currency support - } \\
\text { Only BDT/Taka } \\
\text { 6. Global rich- no } \\
\text { support }\end{array}$ & 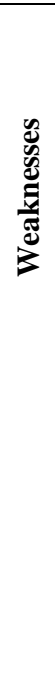 \\
\hline 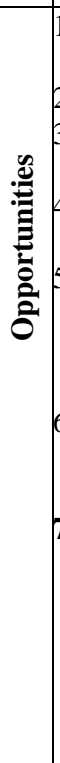 & $\begin{array}{l}\text { 1. Has chance to eliminate } \\
\text { market middlemen } \\
\text { 2. Can create employment } \\
\text { 3. Audiences may gather IT } \\
\text { knowledge } \\
\text { 4. Has option to study of } \\
\text { cultural tradition } \\
\text { 5. Option to run secure } \\
\text { Online payment system- } \\
\text { that helps one step to } \\
\text { steer E banking } \\
\text { 6. M-commerce - that may } \\
\text { cover all target audi- } \\
\text { ences } \\
\text { 7. Rich structure of website } \\
\text {-that may help to run an } \\
\text { ideal E-commerce }\end{array}$ & $\begin{array}{l}\text { 1. Weak Shipping } \\
\text { policy -can lose the } \\
\text { user } \\
\text { 2. Improper web site } \\
\text { design - May dis- } \\
\text { agree the users to } \\
\text { access the site } \\
\text { 3. Limited market } \\
\text { space-can avoid the } \\
\text { consumer } \\
\text { 4. No media publicity- } \\
\text { can away from } \\
\text { competitive envi- } \\
\text { ronment } \\
\text { 5. Going to introduce } \\
\text { E-gateway cards for } \\
\text { both banking e- } \\
\text { commerce transac- } \\
\text { tion which may take } \\
\text { the market of Click- } \\
\text { Cards. }\end{array}$ & 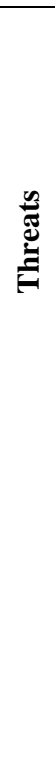 \\
\hline
\end{tabular}

\subsection{Cellbazaar.com}

Table 7. SWOT analysis of Cellbazaar.com [20]

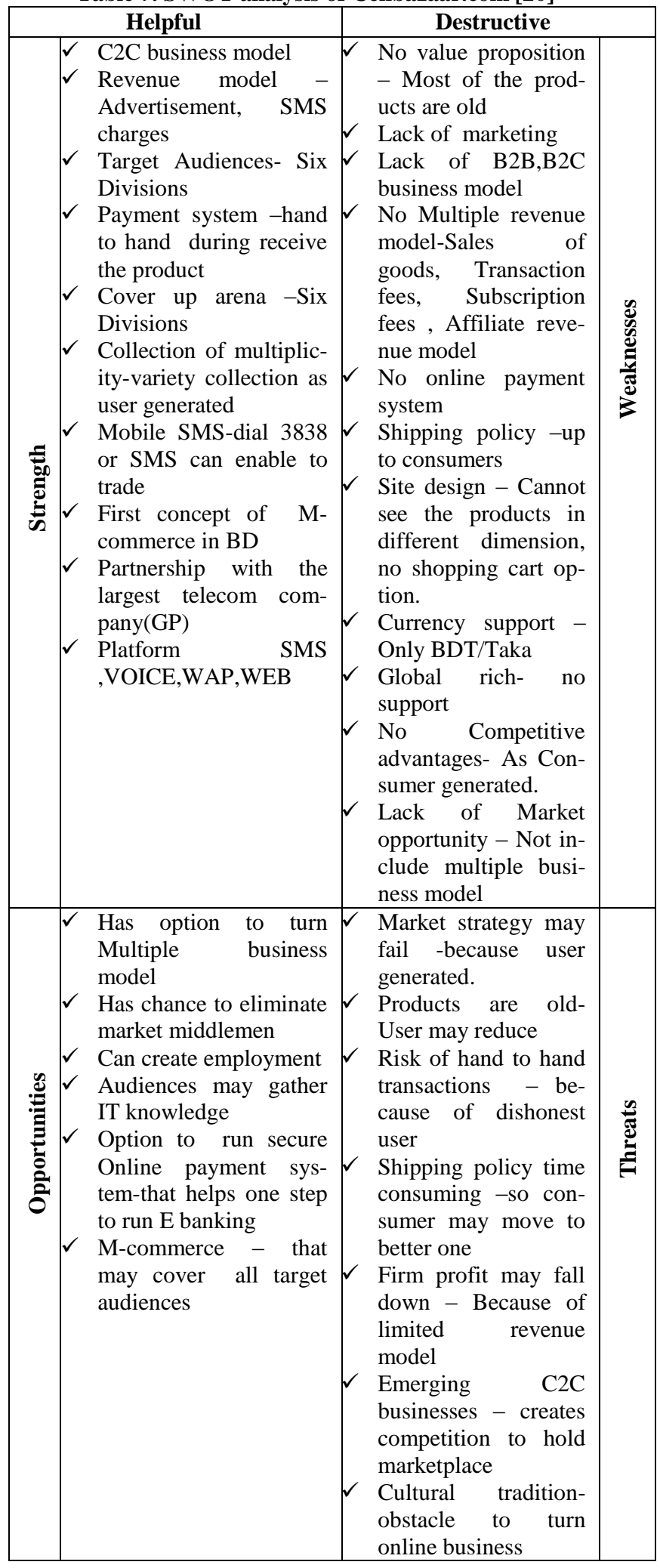




\subsection{Rokomari.com}

Table 8. SWOT analysis of Rokomari.com [21]

\begin{tabular}{|c|c|c|c|}
\hline & Helpful & Destructive & \\
\hline & 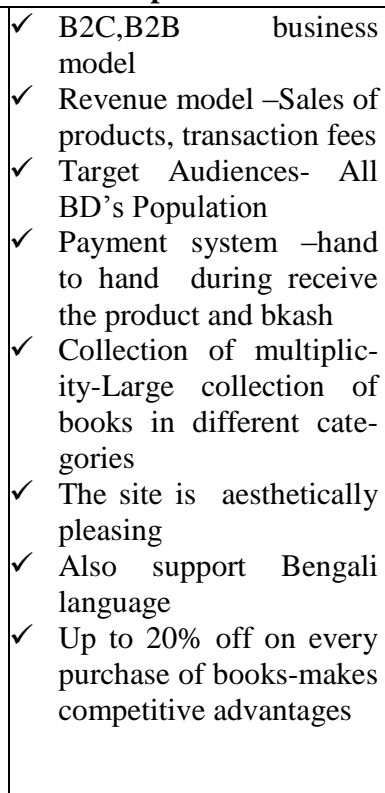 & 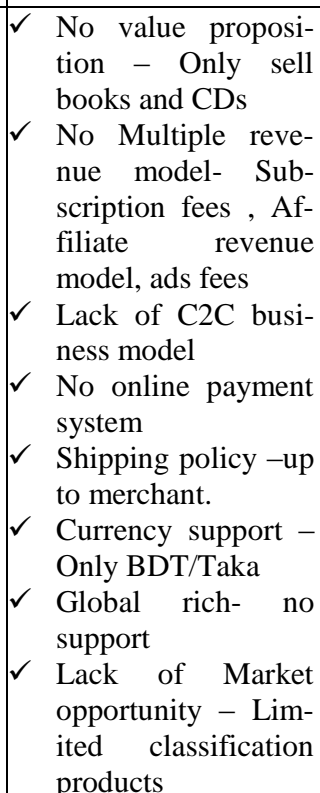 & 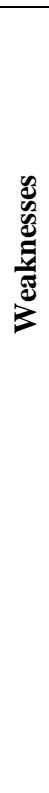 \\
\hline 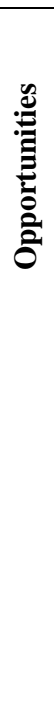 & 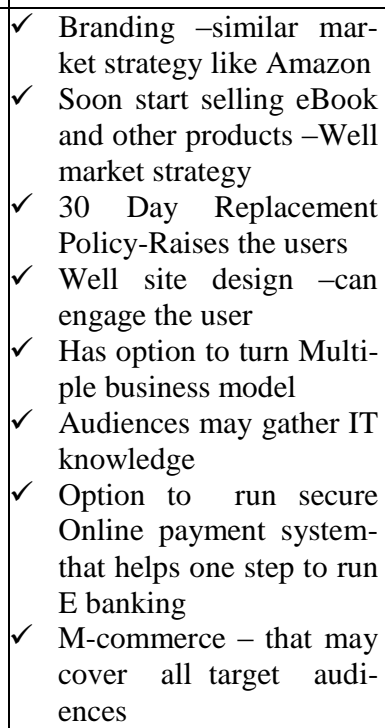 & $\begin{array}{l}\checkmark \text { Replacement policy } \\
\text {-can haphazard } \\
\text { merchant of dishon- } \\
\text { est people } \\
\checkmark \text { Risk of transactions } \\
- \text { one party of a } \\
\text { transaction can } \\
\text { deny. } \\
\checkmark \\
\text { Shipping policy } \\
\text { time consuming -3 } \\
\text { to } 10 \text { working days } \\
\checkmark \\
\text { Firm profit may fall } \\
\text { down - Because } \\
\text { market size is small } \\
\text { Merchant gener- } \\
\text { ated-user can move } \\
\text { other emerging site }\end{array}$ & 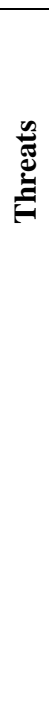 \\
\hline
\end{tabular}

\subsection{Hutbazar.com}

Table 9. SWOT analysis of Hutbazar.com [22]

\begin{tabular}{|c|c|c|c|c|}
\hline & Helpful & & Destructive & \\
\hline 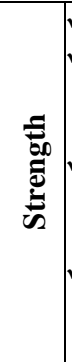 & 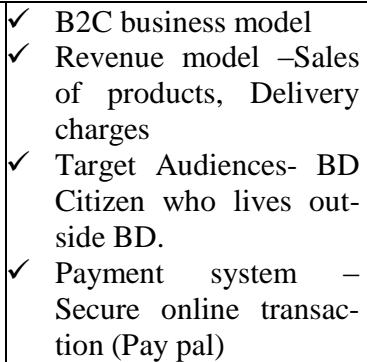 & $\checkmark$ & $\begin{array}{l}\text { No Multiple revenue } \\
\text { model-Advertisement } \\
\text { Subscription fees , } \\
\text { Affiliate revenue } \\
\text { model } \\
\text { Lack of Market } \\
\text { opportunity - be- } \\
\text { cause not include } \\
\text { BD. }\end{array}$ & 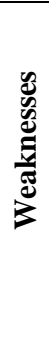 \\
\hline
\end{tabular}

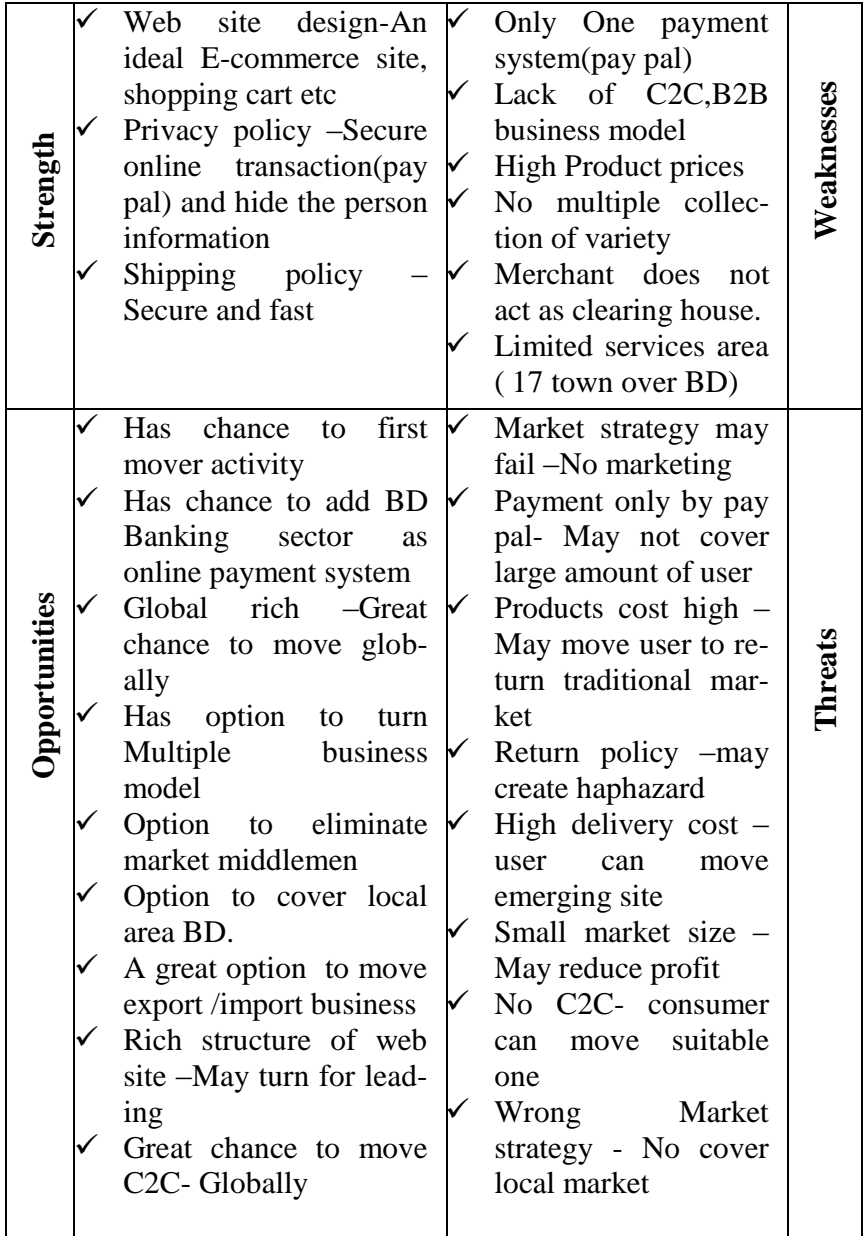

\section{SURVEY AND RESULT FORMULATION}

\subsection{Survey of Different localized audiences in BD}

This study surveyed on 500 hundred people randomly all over the country (BD) through only educated population. Literacy: definition: age 15 and over can read and write Total

population: $56.8 \%$

Male: $61.3 \%$

Female: $52.2 \%$ (2010 EST.)

Definition: This entry includes a definition of literacy and Census Bureau percentages for the total population, males, and females. There are no universal definitions and standards of literacy. Unless otherwise specified, all rates are based on the most common definition - the ability to read and write at a specified age. Detailing the standards that individual countries use to assess the ability to read and write is beyond the scope of the Factbook. Information on literacy, while not a perfect measure of educational results, is probably the most easily available and valid for international comparisons. Low levels of literacy and education in general, can impede the economic development of a country in the current rapidly changing, technology-driven world. 
Source: CIA World Fact book [15]

Literacy (\%)

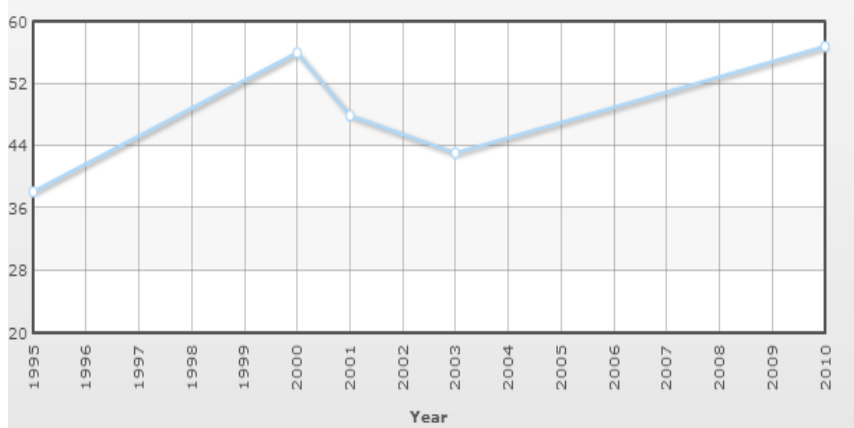

\begin{tabular}{|c|r|r|r|r|r|}
\hline Country & 1995 & 2000 & 2001 & 2003 & 2010 \\
\hline Bangladesh & 38.1 & 56 & 47.9 & 43.1 & 56.8 \\
\hline
\end{tabular}

Fig 1: Last update literature rate of BD.

This survey was based on some questionnaires.

1. Are you Familiar with e-commerce?

a. Yes c. Partial b. No

These percentage values are calculated over 500 literate populations.

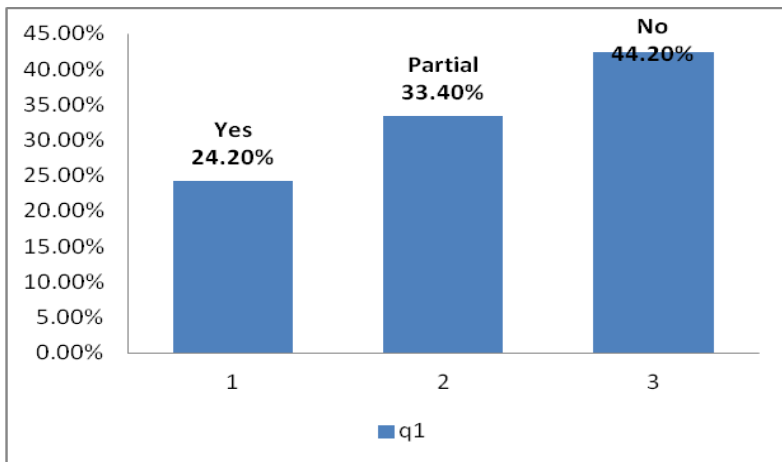

Fig 2: E-commerce familiar percentage values over 500 literate populations.

2. Did/do you use/access this service?

a. Yes b .No

3. Do you agree that e-commerce can provide an alternative marketing channel by eliminating middleman?

a. Yes b. No

4. According to you, is e-commerce suitable or traditional business model for our facilities?

a. Traditional b. E-commerce

These percentage values are calculated over absolute and partial familiar population to E-commerce.

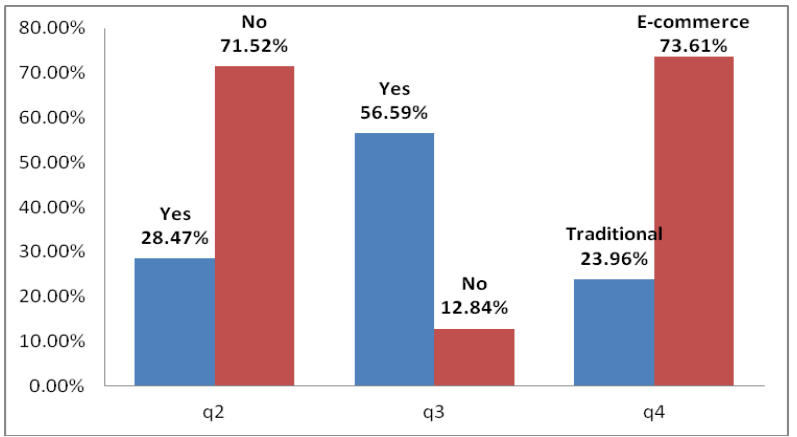

Fig 3. Percentage values for prediction about Ecommerce.
5. How do you access this site?

a. Cell phone b. PC

.6. Did you buy any products from E-commerce sites?

a. Yes b. No

These percentage values are calculated over the population who only access the sites.

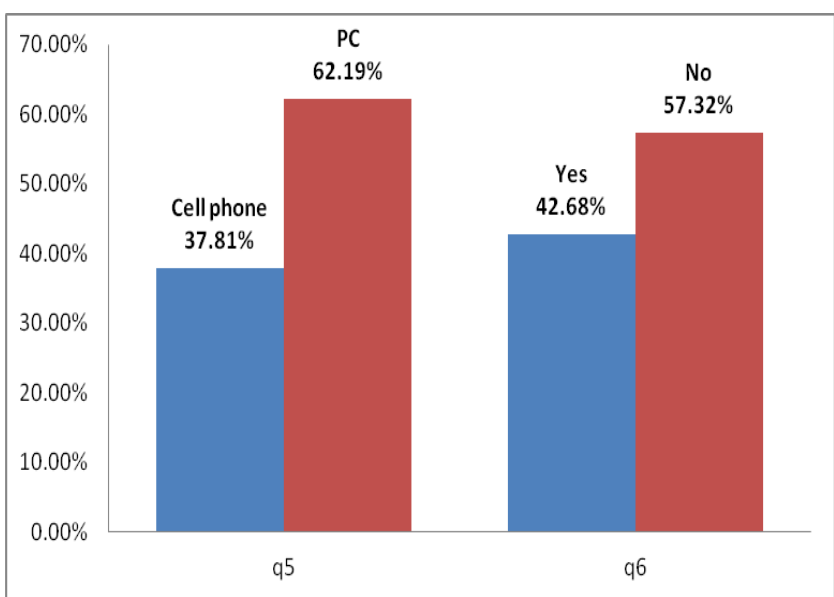

Fig 4. Percentage values on entrance users/consumers

7. How do you pay to buy products /services?

a. Online payment $\quad$ b. Other

8. Which type of business model did you use?

a. b2b b. b2c c. c2c

9. Are you satisfied to receive/get their services?

a. Yes b. Partial c. No

These percentage values are calculated over the population who buy the products or services.

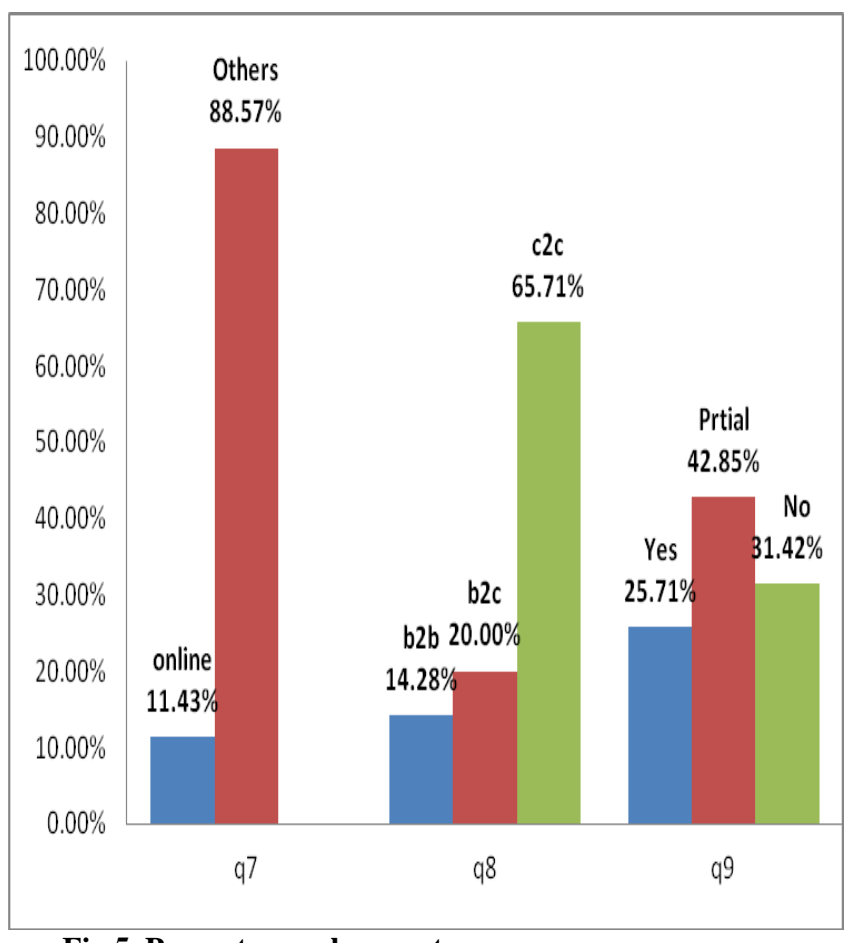

Fig 5. Percentage values on true consumers 
These percentage values are calculated over 500 literate populations.

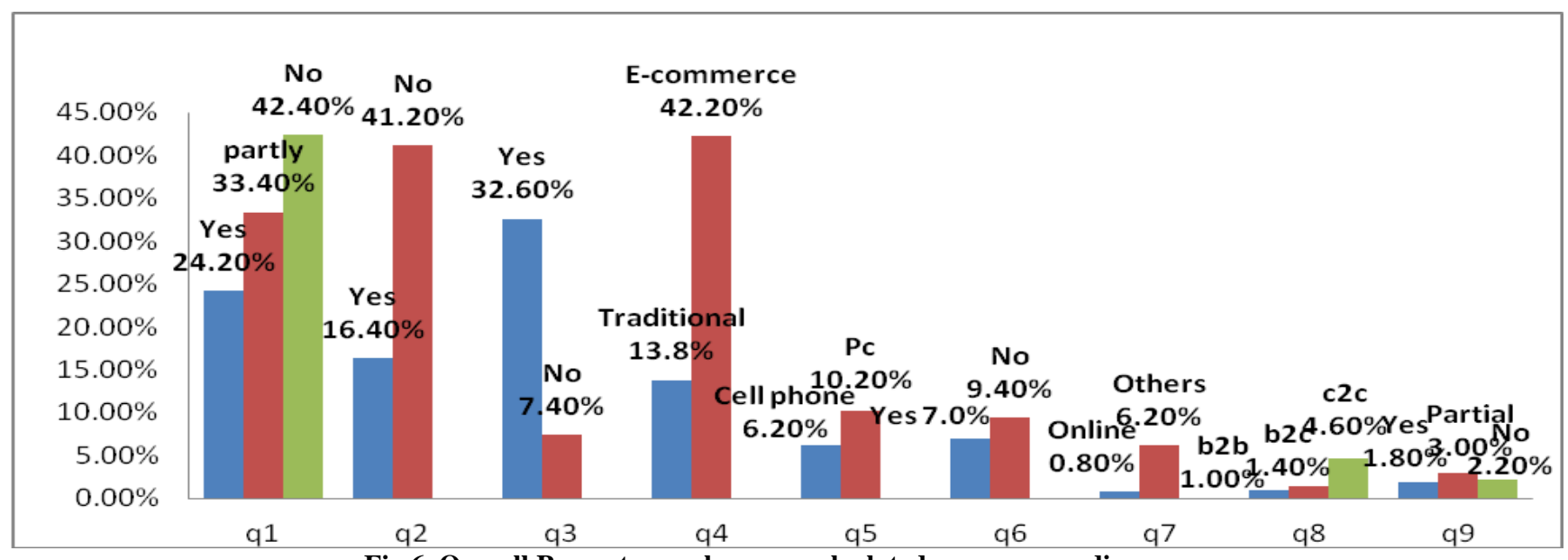

Fig 6. Overall Percentage values are calculated on survey audiences.

\subsection{Survey on E-commerce service provider parties.}

The survey was based on some important questionnaires regarding the online business perspective. This assessment is done through the existing 17 online market sites over the country (BD). The questions are the following:

1. What Kinds of business model do you run?

(a) b 2 b (b) b2c (c) c 2c

2. Mention the major revenue models used in your Ecommerce site.

a. Sales of goods b. Advertise c. Transaction fee

d. Subscription fees

e. Referral fee

3. Do you follow any privacy policy in your site? :

(a) Yes (b) No

4. Is this site cover over the world or designed to service for local area?

a. Local b. Global
5. What are the payment systems in your site?

(a). Manual system (b). Online payment system

6. Does it support any types of currencies?

(a) Local currency (b) Foreign currencies

7. Who are the target audience of your site?

(a) Local (BD) (b) Outside the country

8. Do you thing that the Govt. of BD is doing its enough to promote e-commerce in $\mathrm{Bd}$.

(a)Enough (b) Partial (c) Not at all

9. Do this site has contractual policy with any products delivery parties (Post office, currier service, S.A Paribahan, etc) for delivering products?

(a) Absolutely (b) partial

10. Does this site follow marketing to explore online business?

(a) Fully (b) Partly (c) No

These percentage values are calculated existing 17 online market sites over the country (BD).

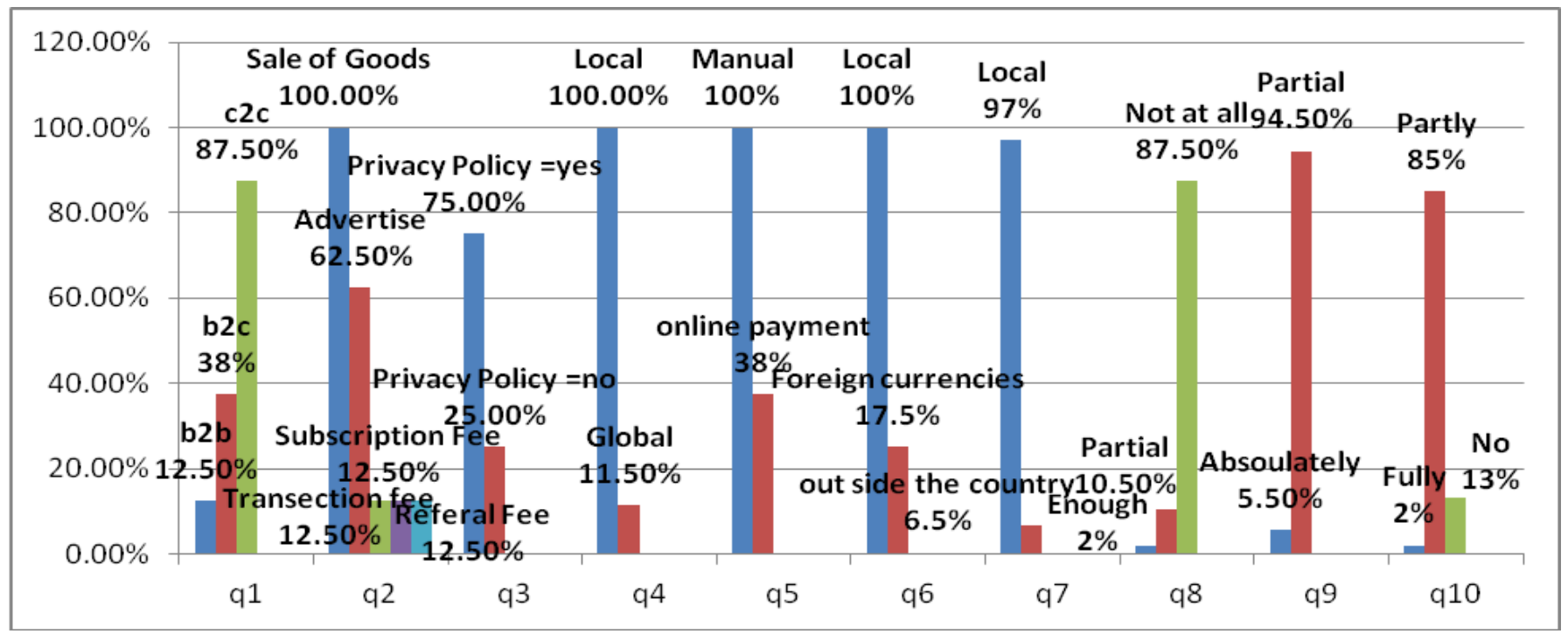

Fig 7: Survey report on online markets. 


\subsection{Comparison Between world wide E- commerce sites versus Local existing E- commerce (BD).}

This assessment is done in the view of some potential aspects. These issues [10] are applied in both cases to evaluate the distinction. The prospective features are such as:

$\checkmark$ Business Dimensions / Models

$\checkmark$ Revenue Model

$\checkmark$ Target audiences

$\checkmark$ E-commerce Website Methodology

$\checkmark$ Secure and quick payment system

$\checkmark$ Currencies Support

$\checkmark$ Shipping policies

$\checkmark$ Collection of multiplicity

$\checkmark \quad$ Businesses cover up arena

$\checkmark$ Privacy policy

Table 10. Comparison world wide E-commerce sites versus Local existing E-commerce (BD). [21][22] [23] [24]

\begin{tabular}{|c|c|c|}
\hline Areas & Bangladesh & Global \\
\hline $\begin{array}{l}\text { Business Di- } \\
\text { mension }\end{array}$ & $\begin{array}{l}\mathrm{B} 2 \mathrm{~B}, \quad \mathrm{~B} 2 \mathrm{C}, \\
\mathrm{C} 2 \mathrm{C}, \\
\text { M-commerce }\end{array}$ & $\begin{array}{l}\mathrm{B} 2 \mathrm{~B}, \mathrm{~B} 2 \mathrm{C}, \mathrm{C} 2 \mathrm{C} \\
\text { M-commerce, P2P }\end{array}$ \\
\hline $\begin{array}{l}\text { Revenue } \\
\text { Model }\end{array}$ & $\begin{array}{l}\text { Sales of } \\
\text { Goods, } \\
\text { Advertisement }\end{array}$ & $\begin{array}{l}\text { Sales of Goods, } \\
\text { Advertisement }\end{array}$ \\
\hline $\begin{array}{l}\text { E-Commerce } \\
\text { Website } \\
\text { Methodology }\end{array}$ & $\begin{array}{l}\text { Development } \\
\text { and Mainte- } \\
\text { nance in a } \\
\text { irregular basis }\end{array}$ & $\begin{array}{l}\text { Development and } \\
\text { Maintenance Continuous } \\
\text { Process }(99.99+\%)\end{array}$ \\
\hline $\begin{array}{l}\text { Target audi- } \\
\text { ences }\end{array}$ & $\begin{array}{l}\text { Native People/ } \\
\text { Local Market }\end{array}$ & International Market \\
\hline $\begin{array}{l}\text { Secure and } \\
\text { quick pay- } \\
\text { ment system } \\
\end{array}$ & Negotiateable & $\begin{array}{l}\text { Well Secured and elec- } \\
\text { tronic transaction }\end{array}$ \\
\hline $\begin{array}{l}\text { Currencies } \\
\text { Support }\end{array}$ & $\begin{array}{l}\text { Almost Local } \\
\text { Currency }\end{array}$ & International Currencies \\
\hline $\begin{array}{l}\text { Shipping poli- } \\
\text { cies }\end{array}$ & Not organized & World Wide \\
\hline $\begin{array}{l}\text { Collection of } \\
\text { multiplicity }\end{array}$ & Poorly & Covers Maximum \\
\hline $\begin{array}{l}\text { Businesses } \\
\text { cover up arena }\end{array}$ & Local & Global \\
\hline $\begin{array}{l}\text { Privacy poli- } \\
\text { cy }\end{array}$ & $\begin{array}{l}\text { Not Trustwor- } \\
\text { thy }\end{array}$ & Trustworthy \\
\hline
\end{tabular}

\section{ARISING CHALLENGES, SOLU- TIONS AND EFFECTIVENESS}

\subsection{Challenges [12]}

There are huge challenges that should be overcome before start ecommerce. Some of these are as follows.

\footnotetext{
$\checkmark \quad$ Lack of education

$\checkmark \quad$ Govt. / Pvt. Corporation noninvolved

$\checkmark$ Cultural tradition

$\checkmark \quad$ Poor concept of online marketing

$\checkmark \quad$ Poor ICT education and training

$\checkmark \quad$ Internet usage cost high

$\checkmark \quad$ No proper agreement for shipping policy

$\checkmark \quad$ Lack of Privacy policy

$\checkmark \quad$ Feeble Site development and maintenance

$\checkmark \quad$ Less marketing or promote
}

$\checkmark \quad$ Political problem

$\checkmark \quad$ Business and enterprise less interested to move

$\checkmark$ Lack of first mover

$\checkmark \quad$ Banking sector are not negotiateable for electrical transaction

$\checkmark \quad$ High cost of products/services comparing traditional market

$\checkmark \quad$ Internet coverage arena is limited.

$\checkmark$ Communication is haphazard over the country

$\checkmark$ Collection of multiplicity is very low.

$\checkmark \quad$ Lack of trustable business and enterprise

$\checkmark \quad$ Lack of experience of meeting directly with merchant and customer

\subsection{Solutions [12]}

'Build a business, not a website.' E-Commerce is not only a website. This is more than this. An e-commerce site is often as distinctive as the business model it follows. For example, any of the following might also apply:

$\checkmark$ Product relationships/suggestions (up-selling)

$\checkmark$ Customized/Personalized products

$\checkmark \quad$ Ticketing and unique code generation (for use on different sites/services)

$\checkmark$ Discounts, Coupons, and Gift Cards

$\checkmark \quad$ Tax calculations and exemptions

$\checkmark \quad$ Multiple currency and multilingual support

$\checkmark \quad$ Fulfillment and inventory management

$\checkmark$ Notifications (both administrative and customer)

$\checkmark$ Reporting

$\checkmark$ One-step checkout

$\checkmark$ Multiple payment methods

$\checkmark$ Data Migration (from an existing store or database)

$\checkmark \quad$ Integration with non-commerce services (e.g. marketing data collection, newsletters, sharing purchase information on a social network)

\subsection{Effectiveness [10][11]}

Effectiveness is the success issue of the work. However, this study observed various triumph in several dimensions that are out come result after exploitation online market.

\section{Mentionable helpfulness issues are depicted below:}

$\checkmark$ Most important role to build up digital Bangladesh.

$\checkmark$ Create a direct relation from manufacturer to consumer

$\checkmark$ Eliminate value chain

$\checkmark$ Eliminate market middlemen

$\checkmark \quad$ Great option to create employment

$\checkmark$ Excellent chance to buy products/services in low cost

$\checkmark$ Abolish the negative cultural tradition

$\checkmark \quad$ Secure and easy payment system

$\checkmark \quad$ Save the consumer time

$\checkmark \quad$ Secure marketing policy

$\checkmark \quad$ Eliminate consumer and provider haphazard scheme

$\checkmark$ Great option to gather IT knowledge

$\checkmark$ Comparatively less capital to open online market space

$\checkmark \quad$ Virtual customer service (Easy and quick)

$\checkmark$ Enormous quality of services

$\checkmark$ Consumer has multiple options to choose the products and services

$\checkmark \quad$ Fast and easy shopping

$\checkmark \quad$ Tremendous grad of services

Supreme bargaining option

$\checkmark \quad$ Mentionable Revenue for the country Etc. 


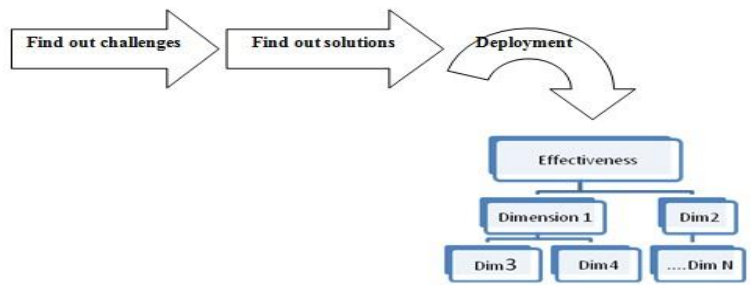

Fig 8: Effectiveness in various dimensions.

\section{CONCLUSION}

From last few decades, organizations have conducted business electronically by employing a variety of electronic commerce solutions. In the conventional scenario, an organization enters the electronic market by establishing trading partner agreements with retailers or wholesalers of their choosing. These agreements may include any items that cannot be acquiescent electronically, such as terms of transfer, payment mechanisms, or implementation conventions. After establishing the proper business relationships, an organization must choose the components of their electronic commerce system. In this paper we formulate current ecommerce issues, challenges and their effective solutions regarding Bangladesh.

In future the authors would like to concentrate on secure payment, e-banking and e-governance.

\section{REFERENCES}

[1] Mir Mohammad Azad and, Md Mahedi Hasan. 2011, Ecommerce aspect of Developing Countries like Bangladesh.

[2] Najmul Hossain. 2000, E-Commerce in Bangladesh: Status, Potential and Constraints.

[3] Md. Raihan Jamil and Muhammad Showkat Imran. 2012, Present Status and Critical Success Factors of ECommerce in Bangladesh.

[4] Kshetri, Nir (2001), "Determinants of the Locus of Global E-Commerce," Electronic Markets, 11(4), 250257.

[5] John Humphrey (IDS), Robin Mansell (LSE), Daniel Paré (LSE) and Hubert Schmitz (IDS). 2003, The Reality of E-commerce with Developing Countries.

[6] Swapna Kodali. 2007, the design and implementation of an e-commerce Site for online book sales. Project Report Submitted to the faculty of the University Graduate School in partial fulfilment of the requirements for the degree, Master of Science.
[7] James Christopher.2004, E-Commerce: Comparison of On-line Shopping Trends, Patterns and Preferences against a Selected Survey of Women.

[8] Kavita and Dr. U.S. 2012, E-Commerce Implementation, Problems, Solutions and Popularity in Managing Supply Chain: A Comparative Analysis of Different Top 10 Indian E-Commerce Companies.

[9] Daniel J. Pare Research Fellow Media@LSE. 2001, B2B E-commerce and Developing Countries.

[10] E-Commerce: Business, Technology and Society (2009) by Kenneth Laudon and Carol Guercio Traver, 4th/later edition.

[11] E-Commerce: Fundamentals and Applications (2001) by Chan, Lee, Dillon and Chang, 1st Edition, reprinted in 2011.

[12] "Bangladesh e-Commerce Week 2013" from 05 -11 January, 2013. Bangladesh Bank and Bangladesh Association of Software and Information Services (BASIS) are jointly going to organize a special awareness and promotional campaign through organizing. http://www.basis.org.bd/resource/Partnership_Proposal_f or_e-commerce-week_2013.pdf

[13] Afroja Ahmed and Mokhtar Ali.2010, The future of Ecommerce in Bangladesh. http://www.slideshare.net/tinna1187/future-of-electroniccommerce-in-bangladesh.

[14] Information Technology in Bangladesh, E-Commerce. http://www1.american.edu/carmel/ap1579a/ecom.htm\#c

[15] Source: CIA World Fact book http://www.indexmundi.com/g/g.aspx? $\mathrm{v}=39 \& \mathrm{c}=\mathrm{bg} \& \mathrm{l}=\mathrm{en}$

[16] http://www.theodora.com/wfbcurrent/bangladesh/bangla desh_people.html

[17] The web information company: http://www.alexa.com/siteinfo/clickbd.com

[18] Online shopping, selling or buying: http://bikroy.com/

[19] Online marketplace: http://www.clickbd.com/

[20] Website for selling and buying in Bangladesh. http://www.cellbazaar.com/

[21] Bangladeshi Online Shopping Portal http://www.rokomari.com/

[22] Online comparison shopping site. http://www.hutbazar.com/

[23] Online shopping site. http://www.amazon.com/

[24] Online shopping site. http://www.ebay.com/ 